\title{
THE IMPACT OF COVID-19 PANDEMIC ON THE ECONOMIC ACTIVITY OF PURSE SEINE FISHERMEN IN BANABUNGI VILLAGE, KADATUA DISTRICT, SOUTH BUTON REGENCY
}

\author{
Azwar Sidiq $^{1}$. Nurhuda Annaastasia ${ }^{2}$. Abdul Sarifin ${ }^{3}$. \\ Yusnita $^{2}$
}

Ringkasan Fisherman are a group of people who are highly dependent on the fisheries resources in their efforts to fulfill their basic needs and to be a prosper. The outbreak of the Covid-19 not only threatens people's lives and safety, but also has a significant impact on economic development both of which are macro and micro to be weakened. This research aims to determine the impacts of the Covid-19 Pandemic on Fishing activities, incomes, and marketing activities of purse seiner. The research was conducted on October 2020 in the Banabungi Village, Kadatua Subdistrict, South Buton Regency, Southeast Sulawesi Province. The results show that the impact of the Covid-19 has affected purse seiner's fishing activities where production costs have increased by 4,62\%, The of crews $(A B K)$ have increased by 19,69\%, and marketing at channel I (Producer-Wholesale)stopped. Consequently, where the change in fish price at fishemen level by $79,75 \%$. The

\footnotetext{
1) 1. Jurusan Agrobisnis Perikanan Fakultas Perikanan dan Ilmu Kelautan Universitas Halu Oleo ${ }^{2}$ ) 2. Jurusan Administrasi Bisnis Fakultas Ilmu Sosial dan Ilmu Politik Universitas Halu Oleo, Jl. H.E.A. Mokodompit, Kota Kendari, Sulawesi Tenggara 93232

E-mail: azwarsidiq@uho.ac.id
}

margin of marketing at channel II at wholesale level is IDR 5.556/kg. Meanwhile, at retail level is IDR $8.267 / \mathrm{kg}$. Production was decreased by $79,93 \%$, revenue decreased by $64,06 \%$ and profit decreased by 68,26\% with value of $R / C$ ratio $3.70>1$. The fishing location of fishermen has not change as in the previous year. Marketing volume during the peak fishing season is 14.809 $\mathrm{kg} / \mathrm{month}$.

Keywords Economic Activity, Banabungi Village, Purse Seiner's, Covid-19 Pandemic

\section{PENDAHULUAN}

Pandemi COVID-19 merupakan peristiwa menyebarnya Virus Corona hingga menjadi bencana global yang mengerikan hampir diseluruh dunia. Dalam waktu yang cukup singkat, beribu-ribu nyawa manusia dari berbagai balahan bumi ini telah menjadi korban keganasan Virus Corona tersebut. Wabah Virus Corona ini masuk ke Indonesia setelah adanya pengumuman resmi dari pemerintah yang disampaikan langsung oleh Presiden pada awal bulan Maret tahun 2020. Sejak saat itu penye- 
baran COVID-19 di Indonesia melesat dengan cepat. Sejak pertama kali dilaporkan kasus positif virus corona maka kenaikan jumlah kasus positif terus bertambah setiap harinya. Pemerintah Republik Indonesia akhirnya mengeluarkan kebijakan berupa Peraturan Pemerintah No. 21 Tahun 2020 tentang Pembatasan Sosial Berskala Besar Dalam Rangka Percepatan Penanganan CoRONA VIRUS DISEASE 2019 (COVID19) untuk mencegah menyebarnya wabah Virus tersebut di Indonesia.

Bukan hanya berdampak secara langsung pada kehidupan manusia (terpapar langsung), secara tidak langsung pandemi ini telah menyebabkan tekanan pada perekonomian nasional (makro). Dampak kebijakan terkait pencegahan penyebaran Virus Corona menyebabkan kegiatan industri perikanan tangkap mengalami tekanan karena kesulitan dalam pengiriman bahan baku, baik melalui transportasi laut maupun udara, sementara itu nelayan akan mengurangi waktu melaut dikarenakan pembatasan aktivitas di pelabuhan -pelabuhan perikanan dan kurangnya penyerapan dari pabrik pengolahan. Belum lagi karena menurunnya permintaan pasar yang pada akhirnya menyebabkan penumpukan bahan baku yang kemudian membuat perusahaan - perusahaan perikanan mengurangi suplai bahan baku.

Ancaman COVID-19 dirasakan oleh semua lapisan masyarakat, tak terkecuali masyarakat yang menggantungkan hidupnya pada sumberdaya kelautan dan perikanan dalam hal ini masyarakat nelayan yang berada di Sulawesi Tenggara. Beberapa kemungkinan dampak yang ditimbulkan adalah penurunan harga ikan karena sulitnya akses pasar sehingga ikan terbuang - buang, permin- taan komoditas perikanan berkurang, pengurangan trip penangkapan, langkanya bahan kebutuhan operasional dan biaya yang dikeluarkan untuk melakukan penangkapan menjadi besar.

Desa Banabungi merupakan salah satu desa yang berada di Kecamatan Kadatua Kabupaten Buton Selatan Provinsi Sulawesi Tenggara. Desa tersebut merupakan salah satu sentra kegiatan perikanan tangkap di Kabupaten Buton Selatan khususnya nelayan pukat cincin atau lebih dikenal dengan istilah purse seine. Jenis alat tangkap ini merupakan jenis alat tangkap yang membutuhkan banyak tenaga/karyawan untuk pengoperasiannya, sehingga dari sisi penyerapan tenaga kerja alat tangkap ini cukup memberikan lapangan pekerjaan walaupun sifatnya tidak terikat. Aktivitas nelayan Purse Seine di Desa Banabungi bisa dikatakan tinggi, sebab trip penangkapan rata-rata dilakukan hanya 1 sampai 2 hari, daerah penangkapannya yang dekat serta lokasi pemasaran yang tidak jauh yakni disekitar desa tersebut dan di Kota Baubau yang letaknya berhadapan dengan Desa Banabungi.

Berdasarkan uraian diatas, maka saya tertarik untuk melakukan penelitian tentang sejauh mana dampak yang ditimbulkan pandemi COVID-19 terhadap aktivitas ekonomi nelayan purse seine di Desa Banabungi Kecamatan Kadatua Kabupaten Buton Selatan Provinsi Sulawesi Tenggara. Istilah dampak pada penelitian ini mengacu pada setiap perubahan yang terjadi pada situasi, kondisi atau konteks akibat Covid-19. Tujuan penelitian ini adalah untuk mengetahui dampak pandemi COVID-19 terhadap aktivitas penangkapan, pendapatan, dan pemasaran nelayan Purse Sei- 
ne di Desa Banabungi Kecamatan Kadatua Kabupaten Buton Selatan.

\section{MATERI DAN METODE}

Penelitian ini dilaksanakan pada bulan Oktober tahun 2020 di Desa Banabungi Kecamatan Kadatua Kabupaten Buton Selatan Provinsi Sulawesi Tenggara yang merupakan salah satu lokasi neelayan purse seine di Kabupaten Buton Selatan Responden ditentuk dengan metode sampling jenuh atau sensus.

Analisis data menggunakan analisis deskriptif kuantitatif dan analisis kuantitatif. Aktivitas penangkapan yang dimaksud dalama penelitian ini meliputi : jumlah trip penangkapan selama satu bulan di musim puncak, Kebutuhan tenaga kerja $\mathrm{ABK}$, Lokasi penangkapan, dan Biaya operasional/biaya produksi. Biaya Produksi adalah biaya yang harus dikeluarkan usaha atau produsen untuk membeli faktor-faktor produksi dengan tujuan menghasilkan output atau produk. Biaya total adalah jumlah total biaya yang dikeluarkan oleh usaha untuk memperoleh input produksi.

$T C=T F C+T V C$

dimana, $\mathrm{TC}=$ Biaya total $(\mathrm{Rp}) \mathrm{TFC}=$ Total bi aya tetap $(\mathrm{Rp})$, yaitu merupakan biaya produksi yang jumlahnya tetap dan tidak terpengaruh dengan jumlah produk yang diproduksi oleh perusahaan. $\mathrm{TVC}=$ Total biaya variabel $(\mathrm{Rp})$, yaitu merupakan biaya produksi yang jumlahnya berubahubah mengikuti jumlah produk yang diproduksi oleh perusahaan.

Analisis penerimaan bertujuan untuk mengetahui seberapa besar penerimaan yang diperoleh dari kegiatan usaha/proyek yang dilakukan. Analisis ini belum melibatkan besaran biaya-biaya yang digunakan. Rumus untuk mengetahui tingkat penerimaan menggunakan rumus menurut Rahardja and Manurung (2008).

$T R=P . Q$

dimana, TR = Total Penerimaan/Total Revenue (Rp) $\mathrm{P}=$ Harga (Rp) Q = Quantitas/Hasil Produksi

Analisis keuntungan bertujuan untuk mengetahui besarnya keuntungan yang diperoleh dari suatu kegiatan usaha/proyek yang dilakukan.

$\pi=T R-T C$

dimana, $\pi=$ Keuntungan $(\mathrm{Rp}) ; \mathrm{TC}=$ Biaya total (total cost) (Rp); dengan kriteria, jika TR $>$ TC maka usaha menguntungkan; jika TR = TC maka usaha pada titik keseimbangan (titik impas); dan jika TR < TC maka usaha mengalami kerugian

Menurut Soekartawi (1989), Analisis $\mathrm{R} / \mathrm{C}$ Rasio adalah analisis yang menunjukan besar penerimaan usaha yang diperoleh petani untuk setiap rupiah biaya yang dikeluarkan untuk kegiatan usaha, semakin besar nilai $\mathrm{R} / \mathrm{C}$ rasio maka akan semakin besar pula penerimaan usaha yang diperoleh untuk setiap rupiah biaya yang dikeluarkan. Kegiatan usaha yang dikategorikan layak jika memiliki nilai $\mathrm{R} / \mathrm{C}$ rasio $>1$, artinya setiap tambahan biaya yang dikeluarkan akan menghasilkan tambahan penerimaan yang lebih besar dari pada tambahan biaya atau secara sederhana kegiatan usaha menguntungkan. Sebaliknya dikategorikan tidak layak jika memiliki nilai $\mathrm{R} / \mathrm{C}$ rasio $<1$ yang berarti untuk setiap tambahan biaya yang dikeluarkan akan menghasilkan tambahan biaya atau kegiatan usaha merugikan. Sedangkan untuk kegiatan usahatani yang memiliki nilai $\mathrm{R} / \mathrm{C}$ rasio $=1$ berarti kegiatan usaha berada 


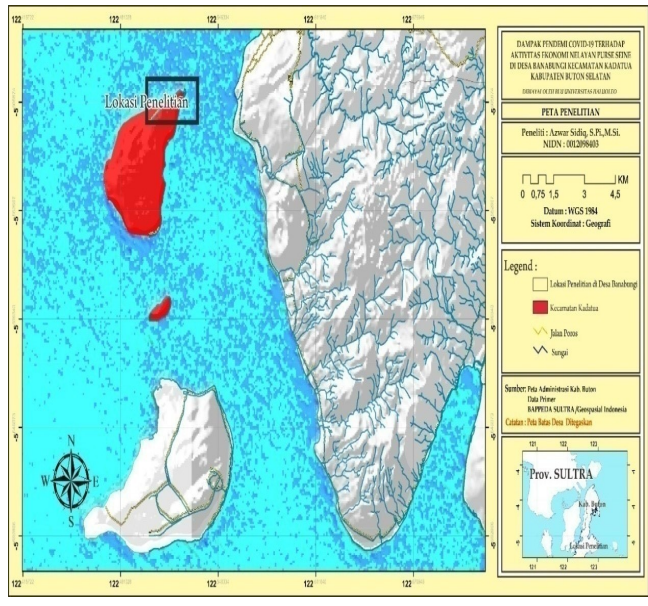

Gambar 1 Peta Lokasi Penelitian

pada keuntungan normal (normal profit).

$R / C=\frac{T R}{T C}$

dimana, $\mathrm{R} / \mathrm{C}=$ Rasio perimbangan penerimaan dan biaya; dengan kriteria : R/C $>1$, usaha/proyek menguntungkan $\mathrm{R} / \mathrm{C}<1$, usaha/proyek rugi $\mathrm{R} / \mathrm{C}=1$, usaha/proyek impas

Bentuk saluran pemasaran diperoleh berdasarkan data survei terhadap jalur pemasaran yang dimulai dari nelayan sampai ke konsumen. Analisis saluran pemasaran untuk mengetahui lembaga lembaga pemasaran yang terlibat dari produsen hingga produk berada di tangan konsumen. Serta fungsi-fungsi pemasaran apa saja yang dilakukan oleh lembaga pemasaran yang terlibat (Kartasapoetra et al., 1986).

\section{HASIL DAN PEMBAHASAN}

Desa Banabungi terletak dalam wilayah administrasi Kecamatan Kadatua. Letak Kecamatan Kadatua dilihat dari peta Kabupaten Buton Selatan berada di tengah-tengah dan disebelah barat daerah Pulau Buton yang terdiri dari Pulau Kadatua dan sebagian Pulau
Liwutongkidi. Batas-batas wilayah Kecamatan Kadatua adalah sebagai berikut :

- Di sebelah Utara berbatasan dengan Laut Flores.

- Di sebelah Selatan berbatasan dengan Selat Siompu.

- Di sebelah Timur berbatasan dengan Selat Masiri.

- Di sebelah Barat berbatasan dengan Laut Flores.

Potensi perikanan di Kecamatan ini yakni pada tahun 2019 tercatat sebanyak 654 Rumah Tangga Perikanan (RTP). Produksi perikanan tangkap pada tahun 2019 yakni sebanyak 1.971,00 ton (BPS (2020)). Produksi perikanan di kecamatan ini terdiri dari jenis ikan tongkol, layang, cakalang, tuna, selar, kembung, ikan terbang, kerapu, kakap, baronang, tenggiri, cumi-cumi, kuwe, gurita, kakatua, katamba dan jenis ikan lainnya.

Desa Banabungi sendiri memiliki luas wilayah $4,13 \mathrm{Km}^{2}$ dengan jumlah penduduk sebanyak 1.238 jiwa yang terdiri dari 564 laki-laki dan 674 perempuan dan 328 kepala keluarga. Berikut adalah peta lokasi penelitian di Desa Banabungi Kecamatan Kadatua Kabupaten Buton Selatan.

Sejak menyebarnya virus Corona di Provinsi Sulawesi Tenggara tepatnya sekitar bulan Maret semua aktivitas masyarakat menjadi terbatas, apalagi sejak diterapkannya PSBB sekitar bulan April tahun 2020. Bulan Januari sampai Maret tahun 2020 nelayan purse seine di Desa Kadatua memang tidak melakukan produksi karena bertepatan dengan musim paceklik dimana nelayan tidak mampu untuk melaut karena angin 
dan gelombang di Musim Barat. Penerapan kebijakan new normal di bulan Juni, nelayan kemabali beraktivitas karena musim penangkapan (musim sedang) sudah dimulai pada awal bulan Mei tahun 2020.

Musim penangkapan ikan di Desa Banabungi secara umum dibedakan atas 3 musim yakni musim puncak (bulan September, Oktober, November), musim sedang (bulan April, Mei, Juni, Juli, Agustus), dan musim paceklik (bulan Januari, Februari, Maret, Desember). Pada musim paceklik, rata-rata nelayan purse seine tidak melakukan penangkapan sama sekali disebabkan oleh cuaca yang (musim barat) sehingga mereka lebih memilih untuk tetap dirumah. Aktivitas penangkapan oleh nelayannelayan purse seine yang berada di Desa Banabungi secara umum dilakukan hanya satu hari saja (one day fishing). Nelayan-nelayan mulai meninggalkan dermaga atau tempat labuh (fishing base) pada pukul 18.00 WITA seletelah shalat Magrib dan kembali pada pagi hari sekitar pukul 06.00 sampai pukul 07.00. Aktivitas penangkapan ikan meliputi beberapa bagian penting diantaranya penggunaan biaya operasional (biaya variabel), lokasi penangkapan, kebutuhan jumlah ABK dan jumlah produksi yang dihasilkan.

Biaya produksi ini terdiri dari biaya variabel (variable cost) dan biaya tetap (fixed cost). Besarnya biaya yang dikeluarkan tergantung pada besarnya kebutuhan yang dikeluarkan termasuk besar kecilnya harga persatuan unit biaya operasional. Berdasarkan hasil analisis yang dilakukan, terdapat perubahan biaya produksi dari aktivitas penangkapan kapal purse seine pada musim puncak tahun sebelumnya (2019). Perubah-
Tabel 1 Rata-rata biaya produksi nelayan purse seine musim puncak tahun 2019 dan tahun 2020 di Desa Banabungi Kecamatan Kadatua Kabupaten Buton Selatan

\begin{tabular}{lllc}
\hline \multirow{2}{*}{ Responden } & \multicolumn{2}{c}{ Biaya Produksi (Rp/Bulan) } & \multirow{2}{*}{ Persentase } \\
\cline { 2 - 3 } \cline { 2 - 3 } KM. Cahaya Ilahi & 2019 & Tahun 2020 & \\
KM. Leletepa & 25.0811 .167 & 31.251 .167 & 6,26 \\
KM. 2 Putri & 20.431 .718 & 25.084 .583 & 0,00 \\
KM. Bintang Baru & 19.524 .208 & 21.691 .718 & 6,17 \\
KM. 21 & 20.551 .824 & 21.651 .824 & 4,30 \\
KM. 05 & 18.541 .095 & 19.261 .095 & 5,35 \\
KM. Sinar Laut 02 & 23.092 .500 & 24.472 .500 & 3,88 \\
KM. Nur Ilahi & 26.529 .167 & 27.729 .167 & 5,98 \\
KM. Mahaputra 2 & 26.888 .833 & 28.268 .833 & 4,52 \\
Rata-Rata & 23.339 .455 & 24.419 .455 & 5,13 \\
\hline
\end{tabular}

an rata-rata jumlah biaya produksi dapat lihat pada Tabel 1.

Selama masa vandemi COVID-19 besaran biaya operasional menunjukan ratarata persentase perubahan sebesar 4,62\%. Berdasarkan hasil penenlitian yang dilakukan diketahui bahwasanya perubahan tersebut disebabkan oleh adanya perubahan harga BBM dimana pada tahun 2019 rata-rata harga BBM Rp 120.000 /jergen ( 1 jergen=20 liter) atau Rp 6000 /liter, sedangkan pada tahun 2020 atau dalam masa vandemi COVID-19 harga BBM ditingkat nelayan meningkat menjadi Rp 140.000 /jergen atau Rp 7000 /liter. Kenaikan harga BBM tersebut lebih disebabkan oleh saluran pemasaran BBM melalui pengecer. Nelayan kebanyakan membeli BBM tidak secara langsung ke Pertamina Nelayan melainkan melalui pengecer BBM. Masa pandemi COVID-19 tidak menyebabkan kenaikan BBM secara langsung, tetapi disebabkan oleh penambahan aktivitas pengecer BBM. Rata-rata biaya operasional atau biaya penangkapan nelayan purse seine di Desa Banabungi Kadatua Kabupaten Buton Selatan adalah Rp 24.419.455 /bulan. Kecilnya biaya yang digunakan tersebut disebabkan karena beberapa input produksi seperti penyediaan Es untuk pe- 
ngawet tidak dibutuhkan dan lokasi penangkapan yang relatif dekat dari fishing base. Biaya tersebut lebih kecil dibandingkan dengan hasil penelitian Utomo et al. (2013) dimana rata-rata biaya operasional purse seine mini di Kecamatan Juwana Kabupaten Pati sebesar Rp 799.900.000 per tahun. Penelitian Farida et al. (2019), rata-rata biaya operasional penangkapan kapal purse seine di Pelabuhan Perikanan Pantai Tasikagung Rembang adalah sebesar Rp 511.099.200 /trip.

Lokasi penangkapan oleh kapal-kapal purse seine yang berada di Desa Banabungi merupakan lokasi perairan dimana terdapat rumpon atau lokasi perairan umum yang terlihat gerombolan ikan target. Berdasarkan hasil penelitian yang dilakukan, lokasi penangkapan ikan berada disekitar Pulau kadatua, Pulau Siompu (Kecamatan Siompu Barat), Teluk Sampolawa, Perairan Mawasangka, Pulau Talaga, Perairan Lande dan Perairan Batuatas. Selama masa Vandemi COVID-19 lokasi penangkapan tidak berubah.

Aktivitas penangkapan ikan oleh nelayan purse seine di Desa Banabungi Kecamatan Kadatua Kabupaten Buton Selatan terdiri atas nelayan pemilik dan ABK. Nelayan pemilik merupakan nelayan pemilik unit kapal penangkapan dan berperan dalam menyediakan biaya operasional atau biaya produksi. Namun demikian sebagian besar nelayan pemilik terlibat juga dalam kegiatan penangkapan ikan. sedangkan ABK berperan dalam menyediakan sumberdaya tenaga kerja secara langsung terlibat dalam kegiatan penangkapan ikan dengan pembagian tugas masing-masing.

ABK yang berkerja pada kapal purse seine di Desa Banabungi rata-rata ada-
Tabel 2 Jumlah ABK kapal purse seine selama musim puncak tahun 2019 dan tahun 2020 di Desa Banabungi Kecamatan Kadatua Kabupaten Buton Selatan

\begin{tabular}{lccc}
\hline \multirow{2}{*}{ Responden } & \multicolumn{2}{c}{ Jumlah Abk (Orang) } & \multirow{2}{*}{ Persentase } \\
\cline { 2 - 3 } & Tahun 2019 & Tahun 2020 & \\
\hline KM. Cahaya Ilahi & 25 & 30 & 20,00 \\
KM. Leletepa & 23 & 29 & 26,09 \\
KM. 2 Putri & 17 & 25 & 47,06 \\
KM. Bintang Baru & 25 & 28 & 12,00 \\
KM. 21 & 25 & 28 & 12,00 \\
KM. 05 & 26 & 26 & 0,00 \\
KM. Sinar Laut 02 & 27 & 32 & 18,52 \\
KM. Nur Ilahi & 27 & 30 & 11,11 \\
KM. Mahaputra 2 & 23 & 30 & 30,43 \\
Rata-Rata & 24 & 29 & 19,69 \\
\hline
\end{tabular}

lah warga asli Desa Banabungi dan merupakan kerabat keluarga. Berdasarkan hasil penelitian jumlah ABK yang berkerja pada setiap kapal purse seine berbeda-beda dan tidak menetap (tidak terikat) (Tabel 2).

Berdasarkan hasil penelitian terjadi peningkatan jumlah ABK yakni rata-rata sebesar $19,69 \%$. Pada masa pandemi COVID-19 banyak anak muda Desa Banabungi yang sebelumnya merantau ke daerah Papua dan Maluku dipulangkan ke wilayahnya, dan dalam masa itu juga mereka tidak bisa merantau keluar daerah. Akibatnya banyak yang memilih menjadi ABK pada kapal purse seine di Desanya. Pemilik kapal atau "punggawa" dan nahkoda tidak bisa untuk menolak permintaan mereka untuk ikut menjadi ABK disebabkan hubungan sosial dan kekerabatan keluarga. Pranata sosial dalam masyarakat nelayan menyebabkan pemilik kapal tidak mampu untuk menolak permintaan mereka untuk menjadi tenaga kerja sebagai ABK. Seperti yang dinyatakan oleh Nurlinah (2008) bahwasanya sistem rekrut sawi didasarkan terutama pada hubungan hubungan kekerabatan, demikianlah muncul kelompok - kelompok punggawasawi yang pada umumnya terdiri dari orang-orang sekeluarga atau sekerabat. 
Tabel 3 Perubahan jumlah produksi nelayan purse seine pada musim pucak tahun 2019 dan tahun 2020 di Desa Banabungi Kecamatan Kadatua Kabupaten Buton Selatan

\begin{tabular}{lccc}
\hline \multirow{2}{*}{ Responden } & \multicolumn{2}{c}{ Jumlah Produksi (Kg/Bulan) } & Persentase \\
\cline { 2 - 3 } & Tahun 2019 & Tahun 2020 & \\
\hline KM. Cahaya Ilahi & 69 & 10.24 & $-85,16$ \\
KM. Leletepa & 68 & 15.6 & $-77,06$ \\
KM. 2 Putri & 105 & 25.2 & $-76,00$ \\
KM. Bintang Baru & 84 & 14.4 & $-82,86$ \\
KM. 21 & 66 & 12.6 & $-80,91$ \\
KM. 05 & 72 & 13.6 & $-81,11$ \\
KM. Sinar Laut 02 & 80.5 & 11.64 & $-85,54$ \\
KM. Nur Ilahi & 44 & 14.4 & $-67,27$ \\
KM. Mahaputra 2 & 85 & 15.6 & $-81,65$ \\
Rata-Rata & 74.833 & 14.809 & $-79,73$ \\
\hline
\end{tabular}

Adapun pengetahuan dan keterampilan kerja diperoleh melalui pewarisan atau pengalaman secara langsung.

Bagi hasil antara pemilik kapal dan ABK di Desa Banabungi dilakukan atas kesepakatan bersama, biasanya dilakukan dalam satu musim penangkapan yakni 18-23 trip/hari dalam 1 bulan. Seperti yang dinyatakan oleh Bachtiar (1997) dalam Multazam (2018), bahwa hubungan kerjasama setelah adanya perjanjian kerja antara punggawa dan sawi dimulai dengan pihak sawi mengikatkan diri untuk bekerja pada punggawa dengan kesepakatan-kesepakatan tertentu yang telah disetujui bersama. Oleh karena sangat jelas bahwa hubungan tersebut bersaskan kekeluargaan, kepentingan bersama, kepercayaan serta asas saling menghormati.

Kegiatan penangkapan ikan nelayan purse seine dalam satu musim penangkapan/satu bulan yakni antara $18-23$ hari. Besaran jumlah produksi nelayan kapal purse seine di Desa Banabungi Kecamatan Kadatua Kabupaten Buton Selatan dapat dilihat pada Tabel 3.

Rata-rata jumlah produksi tangkapan nelayan purse seine di Desa Banabungi pada musim puncak tahun 2020 adalah 14,809 ton/bulan, dengan total ha-

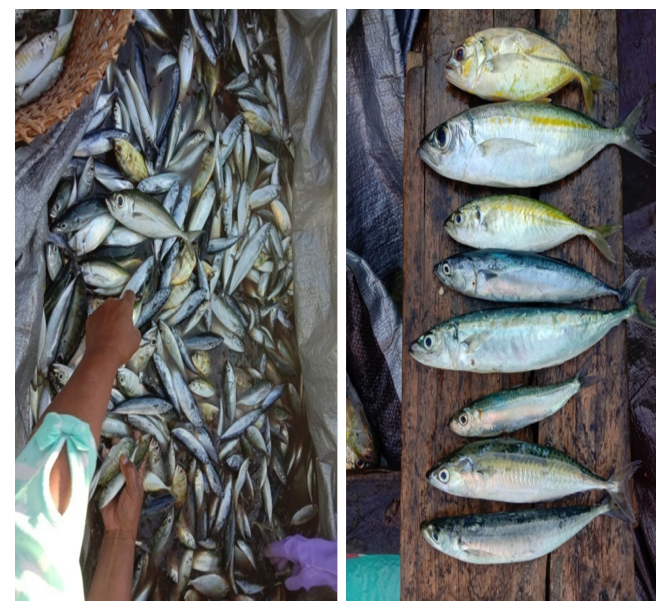

Gambar 2 Komposisi jenis ikan hasil tangkapan nelayan purse seine

sil tangkapan dari seluruh responden sebesar 133,280 ton/bulan. Hasil tangkapan ikan nelayan purse seine terlihat cukup beragam, namun jenis ikan dominan hanya terdiri dari jenis, yakni ikan Tongkol (Euthynnus affinis), ikan Layang (Decapterus, sp), dan ikan Selar Bentong (Selar crumenophthalmus) (Gambar 2).

Berdasarkan data di atas, terlihat bahwasanya terjadi penurunan produksi hasil tangkapan pada masa pandemi COVID19 yakni rata-rata sebesar $79,73 \%$. Berdasarkan informasi dari nelayan, penurunan produksi tersebut disebabkan oleh fenomena alam dimana lokasi-lokasi $f i$ shing ground yang selama ini merupakan lokasi tangkap, tidak terdapat banyak ikan seperti pada tahun sebelumnya. Seperti yang diungkapkan oleh semua responden, fenomena tersebut baru terjadi pada tahun ini. Selain itu juga terdapat fenomena lain dimana ikanikan buntal famili tetraodontodae yang oleh masyarakat setempat menyebunya "kabeka-beka" sangat banyak terdapat di bawah rumpon. Kondisi tersebut menyebabkan nelayan jarang untuk melakukan penangkapan ikan di rumpon, 
Tabel 4 Rata-rata jumlah penerimaan nelayan purse seine pada musim puncak tahun 2019 dan tahun 2020 di Desa Banabungi Kecamatan Kadatua Kabupaten Buton Selatan

\begin{tabular}{lccc}
\hline \multirow{2}{*}{ Responden } & \multicolumn{2}{c}{ Penerimaan (Rp/bulan) } & \multirow{2}{*}{ Persentase } \\
\cline { 2 - 3 } KM. Cahaya Ilahi & Tahun 2019 & Tahun 2020 & \\
KM. Leletepa & 435.562 .500 & 115.200 .000 & $-73,55$ \\
KM. 2 Putri & 476.000 .000 & 135.315 .000 & $-71,57$ \\
KM. Bintang Baru & 735.000 .000 & 148.050 .000 & $-79,86$ \\
KM. 21 & 535.500 .000 & 158.100 .000 & $-70,48$ \\
KM. 05 & 407.550 .000 & 167.400 .000 & $-58,93$ \\
KM. Sinar Laut 02 & 459.000 .000 & 169.200 .000 & $-63,14$ \\
KM. Nur Ilahi & 559.475 .000 & 181.350 .000 & $-67,59$ \\
KM. Mahaputra 2 & 281.600 .000 & 183.300 .000 & $-34,91$ \\
Rata-Rata & 667.250 .000 & 289.800 .000 & $-56,57$ \\
\hline & 506.326 .389 & 171.968 .333 & $-64,06 \%$ \\
\hline
\end{tabular}

mereka lebih memilih untuk menangkap pada perairan lain.

Berdasarkan hasil penelitian yang dilakukan rata-rata tingkat penerimaan dari aktivitas produksi nelayan purse seine di Desa Banabungi Kecamatan Kadatua Kabupaten Buton Selatan dapat dilihat pada Tabel 4.

Tingkat penerimaan kapal purse seine terendah selama musim puncak tahun 2020 adalah Rp115.200.000/bulan, penerimaan tertinggi yakni Rp 289.800.000 /bulan dengan rata-rata penerimaan adalah Rp 171.968.333/bulan. Tingkat penerimaan tersebut berbeda dengan penelitian yang dilakukan Raisi et al. (2019), yakni Rp 27.175.000/trip. Pada tingkat harga yang berlaku sama, perbedaan penerimaan sangat ditentukan oleh jumlah produksi yang hasilkan oleh masing - masing nelayan. Sementara itu persentase perubahan jumlah penerimaan nelayan selama pandemi COVID19 rata-rata menurun sebesar $64,06 \%$. Sekali lagi bahwa penurunan penerimaan tersebut akibat dari menurunnya jumlah produksi yang secara teknis tidak berhubungan dengan masa pandemi COVID19 , tetapi lebih disebabkan oleh berkurangnya ikan di lokasi penangkapan.
Tabel 5 Rata-rata jumlah keuntungan nelayan purse seine musim puncak tahun 2019 dan tahun 2020 di Desa Banabungi Kecamatan Kadatua Kabupaten Buton Selatan

\begin{tabular}{lccc}
\hline \multirow{2}{*}{ Responden } & \multicolumn{2}{c}{ Keuntungan $(\mathrm{Rp} /$ Bulan) } & \multirow{2}{*}{ Persentase } \\
\cline { 2 - 3 } & Tahun 2019 & Tahun 2020 & \\
\hline KM. Cahaya Ilahi & 406.151 .333 & 83.948 .833 & $-79,33$ \\
KM. Leletepa & 450.915 .417 & 158.215 .417 & $-64,91$ \\
KM. 2 Putri & 714.568 .282 & 268.108 .282 & $-62,48$ \\
KM. Bintang Baru & 515.975 .792 & 148.835 .792 & $-71,15$ \\
KM. 21 & 386.998 .176 & 126.398 .176 & $-67,34$ \\
KM. 05 & 440.458 .905 & 138.838 .905 & $-68,48$ \\
KM. Sinar Laut 02 & 536.382 .500 & 110.842 .500 & $-79,34$ \\
KM. Nur Ilahi & 255.070 .833 & 139.670 .833 & $-45,24$ \\
KM. Mahaputra 2 & 640.361 .167 & 153.081 .167 & $-76,09$ \\
Rata-rata & 482.986 .934 & 147.548 .878 & $-68,26$ \\
\hline
\end{tabular}

Berdasarkan hasil penelitian yang dilakukan keuntungan dari aktivitas produksi nelayan purse seine di Desa Banabungi Kecamatan Kadatua Kabupaten Buton Selatan dapat dilihat pada Tabel 5 .

Penurunan rata-rata jumlah produksi pada musim puncak tahun 2020 tentu berimbas pada penurunan tingkat keuntungan. Berdasarkan tabel diatas diketahui bahwasanya rata-rata keuntungan selama masa pandemi COVID-19 (musim puncak tahun 2020) adalah Rp 147.548.878 /bulan, sedangkan jumlah rata-rata keuntungan musim puncak tahun sebelumnya adalah Rp 482.986.939/bulan. Dengan demikian terjadi penurunan keuntungan sebesar $68,26 \%$. Keuntungan nelayan sangat dipengaruhi oleh tingkat harga ikan dan jumlah produksi yang dihasilkan. Hasil penenltian ini sejalan dengan Kholis et al. (2020), dimana nelayan jaring insang diprediksi akan berhutang mulai bulan Juli 2020 sampai bulan Desember 2020, dengan prediksi puncak penurunan pendapatan tertinggi dan awal berhutang pada bulan Juli 2020 dengan persentase sebesar $336 \%$.

Nelayan purse seine memiliki hubungan kerjasama dengan perusahaan penam- 
pung yang berasal dari Jakarta (PT Sinar Binar Perkasa dan Samudera Mandiri). Setiap tahun kapal-kapal penampung datang dan berlabuh disekitar perairan Kadatua untuk mengambil hasil tangkapan nelayan. Harga ikan (Tabel 6) yang diberikan perusahan tersebut relatif konstan. Jenis ikan-ikan yang diterima oleh perusahaan-perusahaan tersebut merupakan komoditi ekspor yakni ikan Tongkol dengan harga Rp 6000 $/ \mathrm{kg}$ dan ikan Layang Rp $9000 / \mathrm{kg}$. Sedangkan jenis ikan Selar tidak termasuk dalam komoditi ekspor, sehingga masuk dalam jalur pasar lokal yakni sekitar Kota Baubau melalui PPI Wameo yang berada di Baubau Harga ikan selar pada tahun 2019 rata-rata $\mathrm{Rp}$ $6.250 / \mathrm{kg}$ ditingkat penampung lokal.

Pada masa pendemi COVID-19 (musim puncak tahun 2020) terjadi perubahan harga ikan-ikan hasil tangkapan nelayan disebabkan oleh perubahan saluran pemasaran dan jumlah produksi yang dihasilkan. Berikut adalah ratarata perubahan harga ikan hasil tangkapan nelayan purse seine di Desa Banabungi Kecamatan Kadatua Kabupaten Buton Selatan.

Berdasakarkan tabel diatas rata-rata perubahan harga ikan ditingkat nelayan pada tahun 2020 adalah 79,75\%. Perubahan harga yang paling besar terjadi adalah jenis ikan Selar yakni 113,33\%. Hasil tangkapan nelayan yang menurun menyebabkan harga-harga ikan cenderung naik. Sedangkan untuk jenis ikan Tongkol dan Layang selain karena jumlah produksi yang sedikit, juga disebabkan oleh perubahan jalur pemasaran yang diakibatkan kuota permintaan perusahaan penampung tidak terpenuhi.
R/C rasio atau Revenue Cost Ratio merupakan perimbangan antara penerimaan dengan tingkat penggunaan biaya produksi. Nilai R/C Ratio berdasarkan hasil analisis kegiatan nelayan purse seine pada musim puncak tahun 2020 dapat dilihat pada Tabel 7.

Berdasarkan tabel di atas menunjukkan rata-rata nilai $\mathrm{R} / \mathrm{C}$ rasio adalah 7,30 lebih besar dari 1 atau usaha nelayan purse seine di Desa Banabungi masih menguntungkan $(\mathrm{R} / \mathrm{C}>1$, usaha/proyek menguntungkan). Artinya adalah bahwa setiap tambahan biaya sebesar Rp1, akan menghasilkan tambahan penerimaan sebesar Rp7,30. Nilai R/C rasio tersebut lebih tinggi dibandingkan dengan hasil penelitian Utomo et al. (2013), dimana nilai $\mathrm{R} / \mathrm{C}$ rasio dari aktivitas nelayan purse seine di Kecamatan Juwana Kabupaten Pati adalah 1,18 untuk purse seine besar, 1,01 untuk purse seine sedang, dan 1,03 untuk purse seine kecil. Dengan demikian terlihat bahwasanya sekalipun dalam masa pandemi COVID-19, usaha perikanan tangkap dalam hal ini aktivitas ekonomi nelayan purse seine di Desa Banabungi Kecamatan Kadatua Kabupaten Buton Selatan masih memberikan keuntungan dan layak untuk diteruskan.

Secara umum kegiatan pemasaran merupakan upaya yang dilakukan oleh seseorang atau badan usaha untuk menyampaikan produknya kepada konsumen. Menurut Kotler (2004) pemasaran adalah suatu proses sosial dan manajerial yang membuat individu dan kelompok memperoleh apa yang mereka butuhkan serta inginkan lewat penciptaan dan pertukaran timbal balik produk dan nilai dengan orang lain. Menurut Mubyarto (1989), pemasaran produk perikanan membutuhan proses yang 
Tabel 6 Harga ikan di Desa Banabungi Kecamatan Kadatua Kabupaten Buton Selatan

\begin{tabular}{|c|c|c|c|c|c|}
\hline \multirow{2}{*}{ Jenis ikan } & Tahun 2019 & \multirow{2}{*}{ Harga ditingkat } & Tahun 2020 & \multirow{2}{*}{ Harga ditingkat } & Persentase \\
\hline & $(\mathrm{Rp} / \mathrm{kg})$ & & $(\mathrm{Rp} / \mathrm{kg})$ & & \\
\hline Tongkol & 6.000 & Perusahaan & 10.667 & penampung Lokal & 77,78 \\
\hline Layang & 9.000 & perusahaan & 13.333 & penampung Lokal & 48,14 \\
\hline Selar & 6.250 & penampung Lokal & 13.333 & penampung Lokal & 113,33 \\
\hline Rata-rata & 7.083 & & 12.444 & & 79,75 \\
\hline
\end{tabular}

Tabel 7 Nilai R/C Ratio kegiatan perikanan kapal purse seine bulan Oktober tahun 2020 di Desa Banabungi Kecamatan Kadatua Kabupaten Buton Selatan

\begin{tabular}{|c|c|c|c|c|}
\hline Responden & Penerimaan Rp/bln & Biaya $(\mathrm{Rp} / \mathrm{bln})$ & Keuntungan $(\mathrm{Rp} / \mathrm{bln})$ & $\mathrm{R} / \mathrm{C}$ rasio \\
\hline KM. Cahaya Ilahi & 115.200 .000 & 31.251 .167 & 83.948 .833 & 3,69 \\
\hline KM. Leletepa & 183.300 .000 & 25.084 .583 & 158.215 .417 & 7,31 \\
\hline KM. 2 Putri & 289.800 .000 & 21.691 .718 & 268.108 .282 & 13,36 \\
\hline KM. Bintang Baru & 169.200 .000 & 20.364 .208 & 148.835 .792 & 8,31 \\
\hline KM. 21 & 148.050 .000 & 21.651 .824 & 126.398 .176 & 6,84 \\
\hline KM. 05 & 158.100 .000 & 19.261.095 & 138.838 .905 & 8,21 \\
\hline KM. Sinar Laut 02 & 135.315 .000 & 24.472 .500 & 110.842 .500 & 5,53 \\
\hline KM. Nur Ilahi & 167.400 .000 & 27.729 .167 & 139.670 .833 & 6,04 \\
\hline KM. Mahaputra 2 & 181.350 .000 & 28.268 .833 & 153.081 .167 & 6,42 \\
\hline Rata-Rata & 171.968 .333 & 24.419 .455 & 147.548 .878 & 7,30 \\
\hline
\end{tabular}

lebih panjang bila dibanding dengan pemasaran produk non perikanan. Hal tersebut terjadi karena produk perikanan (ikan tangkap) membutuhkan perlakuanperlakuan khusus dalam penangan pasca ditangkap dari laut. Oleh karena itu, pemasaran produk perikanan membutuhkan lembaga-lembaga pemasaran dimana lembaga tersebut menjalankan fungsi pemasarannya masing-masing. Berdasarkan hasil penelitian yang dilakukan rata-rata volume pemasaran dari kegiatan produksi nelayan purse seine di Desa Banabungi Kecamatan Kadatua pada masa pandemi COVID-19 (musim puncak bulan Oktober tahun 2020) adalah $14.809 \mathrm{~kg} / \mathrm{bulan}$.

Saluran pemasaran merupakan perjalan suatu produk tertentu dari produsen ke konsumen melalui lembaga-lembaga tertentu yang turut berperan mengambil manfaat didalamnya. Menurut Kotler (2004), saluran pemasaran adalah beberapa organisasi yang saling menguntungkan dan terlibat dalam proses pengupayaan agar produk atau jasa tersedia untuk digunakan dan dikonsum- si. Saluran pemasaran terbentuk karena produsen tidak menjual barangnya secara langsung kepada konsumen akhir, sehingga diperlukan adanya perantara untuk menutupi gap tersebut. Berdasarkan hasil penelitian yang dilakukan terhadap saluran pemasaran produk hasil tangkapan nelayan purse seine di Desa Banabungi Kecamatan Kadatua pada Gambar 3.

Pada tahun 2019 kedua model saluran pemasaran di atas merupakan saluran pemasaran hasil perikanan yang berlaku dari kegiatan penangkapan ikan oleh nelayan purse seine di Desa Banabungi. Pada tahun ini akibat pandemi COVID19 saluran pemasaran I tidak berjalan sama sekali. Pemicu utama disebabkan oleh menurunnya hasil tangkapan nelayan selama musim puncak (bulan SeptemberOktober tahun 2020) sehingga kuota permintaan perusahaan penanmpung tersebut tidak terpenuhi. Kebijakan pemerintah dalam pembatasan kran ekspor yang hampir berlaku diseluruh dunia menyebabkan harga komoditi seperti ikan layang dan tongkol menurun. Ber- 

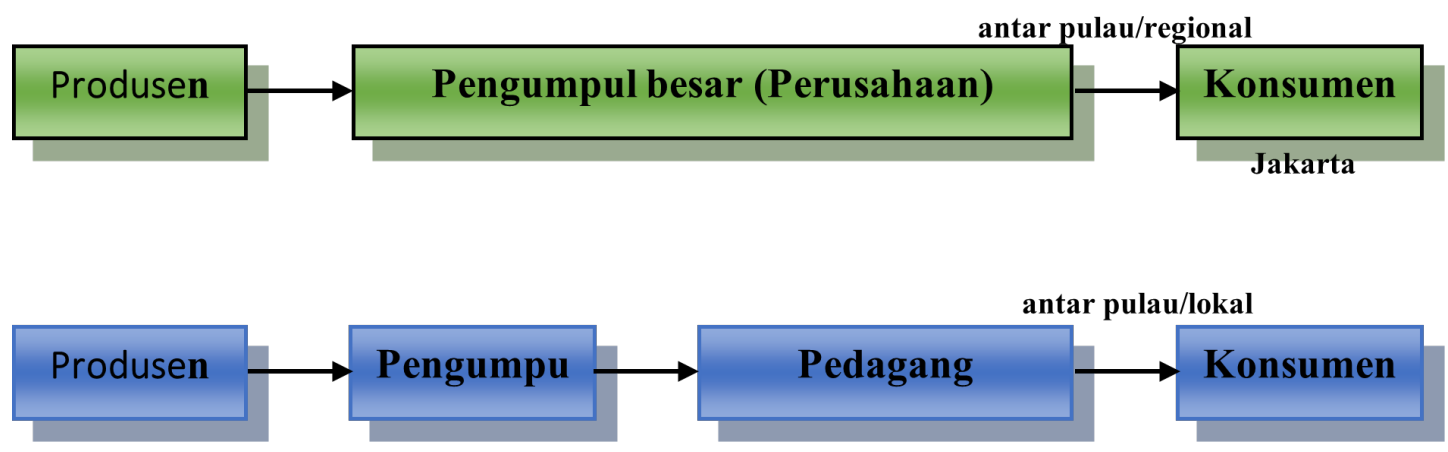

Gambar 3 Saluran pemasaran hasil tangkapan nelayan purse seine Di Desa Banabungi Kecamatan Kadatua Kabupaten Buton Selatan

dasarkan hasil wawancara dengan responden, kapal perusahaan pengumpul besar sempat beberapa hari berlabuh di perairan Desa Banabungi, namun karena hasil tangkapan nelayan yang kurang, perusahaan tersebut meninggalkan tempat menuju ke wilayah lain di daerah Provinsi Sulawesi Tengah. Menurut data Kemenko Maritim dan Investasi, pandemi Covid-19 telah berdampak kepada penurunan harga ikan hingga $50 \%$, penghasilan nelayan turun dari Rp 3,5 juta dalam sekali melaut menjadi Rp1 juta - Rp 1,5 juta.

Selama masa pandemi COVID-19, lembaga pemasaran yang terlibat dalam proses saluran pemasaran hasil tangkapan nelayan purse seine di Desa Banabungi yakni produsen (nelayan purse seine), pengumpul, pedagang pengecer, dan konsumen akhir. Pengumpul dalam saluran pemasaran tersebut sebagian besar adalah warga masyarakat Desa Banabungi yang banyak dilakoni oleh ibuibu yang sebagian merupakan istri dari ABK (Gambar 4). Terdapat juga beberapa pengumpul yang berasal dari daerah lain seperti daerah Lombe Kecamatan $\mathrm{Gu}$. Saluran pemasaran yang terbentuk dalam kegiatan produksi nelayan purse seine hingga sampai kepa- da konsumen akhir merupakan saluran pemsaran tidak langsung.

Selama musim puncak, biaya pemasaran oleh para pengumpul yang berada di Desa Banabungi relatif kecil, sebab mereka cukup menunggu hasil tangkapan nelayan purse seine di lokasi yang telah ditentutkan di Desa Banabungi. Sedangkan pada saat hasil tangkapan sedikit, para pengumpul harus berlombalomba untuk mendapatkan hasil tangkapan nelayan purse seine di tengah laut. Dengan demikian pengumpul harus mengeluarkan biaya transportasi yang cukup besar untuk menuju lokasi tangkap dimana kapal purse seine berada. Hampir seluruh pengumpul yang berada di Desa Banabungi memiliki perahu yang bermesin. Pengumpul di Desa Banabungi akan dihubungi oleh nelayan sesaat setelah ikan ditangkap. Selain biaya transportasi yang harus dikeluarkan, pengumpul juga harus mengeluarkan biaya pengawetan dalam hal ini es. Setiap jumbo membutuhkan 23 es bungkus dengan harga Rp1000/es. Biaya dalam proses pemasaran hasil perikanan ditingkat pengumpul lebih besar dibandingkan dengan biaya pemasaran pada tingkat pedagang pengecer.

Satuan penjualan dari nelayan dalam bentuk keranjang (40 kg), sedangkan 

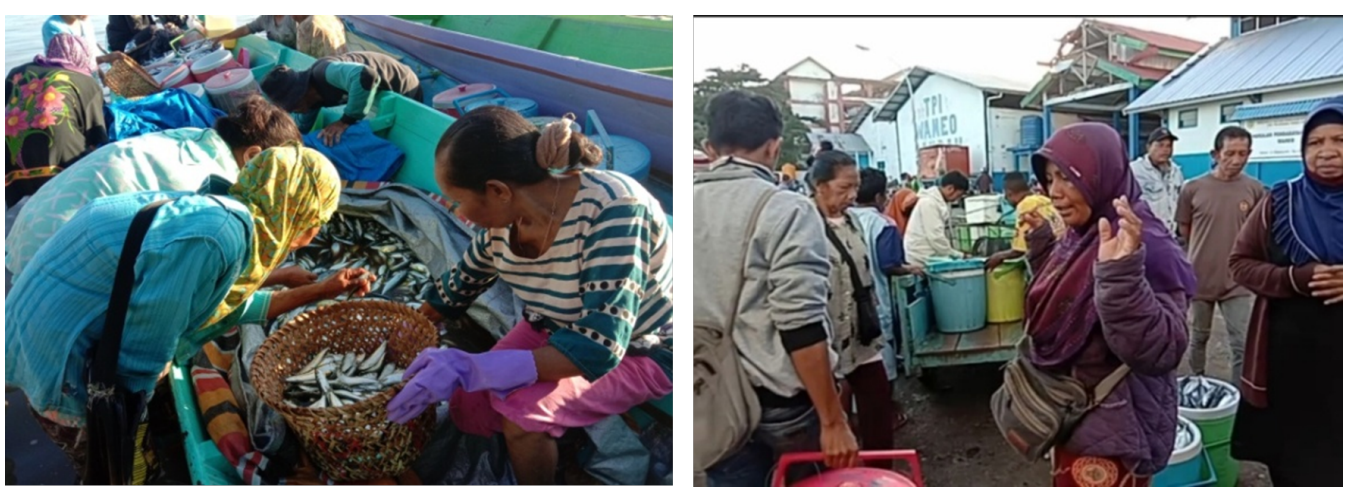

Gambar 4 (a) Aktivitas pengumpul di Desa Banabungi; (b) Aktivitas jual beli pengumpul Ke pengecer di PPI Wameo Kota Baubau

pengumpul akan menjualnya kepada pengecer dalam wadah yang disebut jumbo, dengan rata-rata berat isi $15 \mathrm{~kg} / \mathrm{jum}$ bo. Setiap keranjang dari nelayan ekuivalen dengan 2,5 jumbo. Rahardi et al. (1993), menyatakan bahwa pengumpul merupakan pedagang yang mengumpul barang-barang hasil pertanian dari petani produsen, dan kemudian memasarkannya kembali dalam partai besar kepada pedagang lain.

Selanjutnya ikan yang telah diperoleh akan dipasarkan menuju Pangkalan Pendaratan Ikan (PPI) Wameo yang berada di Kelurahan Tarafu Kecamatan Murhum Kota Baubau. Berdasarkan hasil penelitian yang dilakukan, pengecer yang berada di PPI Wameo sebagian besar adalah mereka yang berdagang di dalam pasar Wameo. Ada juga pedagang pengecer yang berasal dari wilayah lain seperti pedagang pengecer dari Kelurahan Waruruma Kecamatan Kokalukuna Kata Baubau dan Kecamatan Batauga Kabupaten Buton Selatan. Sejak pemerintah Kota Baubau menertibkan pedagang pengecer, para pedagang pengumpul dari Desa Banabungi tidak lagi diperbolehkan untuk menjual langsung pada konsumen akhir dalam pasar Wameo.
Para pedagang pengecer yang berada dalam pasar Wameo dan yang berasal dari tempat lain akan menjemput ikan hasil tangkapan di PPI Wameo pada pagi hari hingga menjelang siang sekitar Pukul 09.00 pagi. Pedagang pengecer dalam pasar Wameo hanya akan mengelurkan biaya pemasaran bahan pengawet berupa es karena jaraknya yang bersampingan dengan PPI Wameo, tidak membutuhkan biaya transportasi. Sedangkan pedagang pengecer yang berasal dari wilayah lain, selain mengeluarkan biaya bahan pengawet juga mengelurkan biaya transportasi. Harga ditingkat pengecer tidak dijual dalam satuan $\mathrm{Kg}$, melainkan dijual persatuan wadah. Satuan wadah yang digunakan biasanya berisi 6 sampai 8 ekor tergantung besar kecilnya ukuran ikan yang dipasarkan. Rata-rata harga penjualan untuk setiap tempat tersebut selama penelitian yakni Rp 20.000. Biasanya satuan penjualan ditingkat pengecer kurang dari $1 \mathrm{~kg}$. Pengecer menurut Rahardi et al. (1993), yaitu pedagang yang menjual barang hasil pertanian ke konsumen dengan tujuan untuk memenuhi kebutuhan dan keinginan konsumen dalam partai kecil. 


\section{SIMPULAN}

Berdasarkan hasil penelitian yang dilakukan, maka dapat ditarik kesimpulan bahwa masa pandemi COVID-19 mempengaruhi aktivitas penangkapan nelayan antara lain penurunan biaya produksi $4,62 \%$, peningkatan penggunaan anak buah kapal (ABK) sebesar 19,69\%, terttutupnya saluran pemasaran I, terjadi perubahan harga ditingkat nelayan sebesar $79,75 \%$. Nilai margin saluran pemasaran II tingkat pengumpul $\mathrm{Rp}$ $5.556 / \mathrm{kg}$, sedangkan ditingkat pengecer Rp $8.267 / \mathrm{kg}$. Pandemi Covid-19 tidak mempengaruhi jumlah produksi yang menurun sebesar $79,73 \%$, penerimaan menurun sebesar $64,06 \%$, keuntungan menurun sebesar $68,26 \%$. Lokasi penangkapan nelayan tidak mengalami perubahan seperti pada tahun sebelumnya. Volume pemasaran selama masa vandemi COVID-19 (musim puncak tahun 2020) adalah sebesar 14.809 $\mathrm{kg} / \mathrm{bulan}$, sedangkam nilai $\mathrm{R} / \mathrm{C}$ rasio adalah 7,30 atau usaha penangkapan masih layak dilaksanakan. Perlu untuk merencanakan strategi prioritas yang dihasilkan melalui penelitian ditingkat pemerintah, sehingga kegiatan nelayan purse seine di Desa Banabungi tetap berjalan.

Acknowledgements : Ucapan terimakasih kami sampaikan kepada Lembaga Penelitian dan Pengabdian Kepada Masyarakat (LPPM) Universitas Halu Oleo yang telah memberikan kepercayaan, sehingga penelitian ini dapat terlakasana dan memberikan hasil dengan baik. Selanjutnya ucapan terimakasih juga kami sampaikan kepada pimpinan Universitas Haluo Oleo, pimpinan Fakultas Perikanan dan Ilmu Kelautan Universitas Halu Oleo, masyarakat Desa Kadatua dan semua pihakpihak yang membantu terlaksanya penelitian ini.

\section{Pustaka}

BPS (2020). Kabupaten buton selatan dalam angka 2020. Technical report, Badan Pusat Statistik Buton Selatan.

Farida, L., Ghofar, A. A., and Solichin, A. (2019). Analisis laba rugi usaha penangkapan kapal mini purse seine di ppp tasikagung rembang analysis income statement of the mini purse seine fishing business at tasikagung fishing port rembang. Management of Aquatic Resources Journal (MAQUARES), 8(3):193-198.

Kartasapoetra, G., Kartasapoetra, A. G., and Kartasapoetra, R. (1986). Marketing produk pertanian dan industri yang diterapkan di Indonesia. PT Bina Nasara, Jakarta.

Kholis, M. N. et al. (2020). Prediksi dampak covid-19 terhadap pendapatan nelayan jaring insang di kota bengkulu. ALBACORE Jurnal Penelitian Perikanan Laut, 4(1):001-011.

Kotler, P. (2004). Keller, 2007, manajemen pemasaran, jilid i, edisi kedua belas, pt. Indeks, Jakarta.

Mubyarto (1989). Pengantar Ekonomi Pertanian. LP3S.

Multazam, S. (2018). Sistem bagi hasil nelayan punggawa-sawi unit pukat cincin (purse seine) di ppi lonrae, kecamatan tanete riattan timur, kabupaten bone. Master's thesis, Fakultas Ilmu Kelautan dan Perikanan Universitas Hasanuddin.

Nurlinah, N. (2008). Reproduksi struktur dalam organisasi nelayan ponggawa-sawi dalam eksploitasi sumberdaya laut di sulawesi selatan. Jurnal Administrasi dan Kebijakan Kesehatan Indonesia, 1(1):63-76.

Rahardi, A., Kristawati, F., and Nazaruddin (1993). Agribisnis Perikana. Penebar Swadaya. 
Rahardja, P. and Manurung, M. (2008). Pengantar ilmu ekonomi. Fakultas Ekonomi Universitas Indonesia. Jakarta, 189.

Raisi, L., Asis, N., and Riani, I. (2019). Analisis keuntungan usaha nelayan purse seine di kecamatan rumbia tengah kabupaten bombana. Jurnal Sosial Ekonomi Perikanan, 4(4).

Soekartawi (1989). Prinsip dasar manajemen pemasaran hasil-hasil pertanian: teori dan aplikasinya. Rajawali.

Utomo, M. T., Djasmani, S. S., Saksono, H., and Suadi, S. (2013). Analisis usaha purse seine di kecamatan juwana kabupaten pati. Jurnal Perikanan Universitas Gadjah Mada, 15(2):91-100.

Kontribusi: Sidiq, A: Mengambil data Lapangan, menulis manuscript, pembahasan; Annaastasia, N: Analisis Data, dan pembahasan; Sarifin, A: Merangkum dan menulis pembahasan; dan Yusnita:Analisis Data. 